\title{
Ground-Water Flooding in Glacial Terrain of Southern Puget Sound, Washington
}

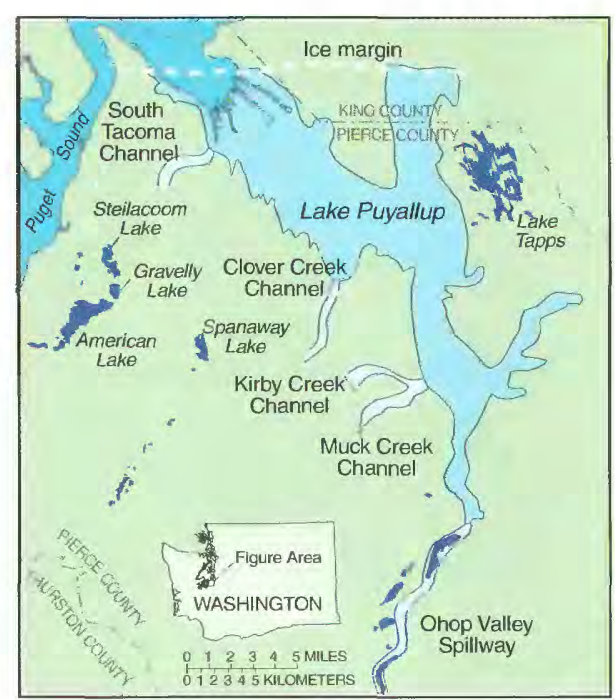

Figure 1. Proglacial Lake Puyallup and successive Lake Spillways (modified from Thorson, 1979).

round-water flooding happens in table rises above the land surface. In the complex glacial geologic framework of southern Puget Sound, this phenomenon can occur along former outwash channel depressions after two or more consecutive years of above-average precipitation. It has also occurred and been documented in the glacial environment found in Illinois. ${ }^{12}$ An examination of the geomorphic history and processes associated with the last period of glaciation provides insight on the causes of this unique and persistent flooding problem of the southern Puget Sound.

The present topographic shape and
form of the southern Puget Sound Lowland has been largely influenced by the most recent glacial advance and retreat. The passage of the glacier from north to south left distinctive landforms, such as ice contact, north-south-trending depressions, outwash channels, kettles, and drumlins. The last extensive glaciation of the southern Puget Sound was the Vashon Stade of the Fraser Glaciation. The glacier advanced from the north into the Puget Sound Lowland about 18,000 years ago, impounding rivers, creating glacial lakes, and diverting drainage southward to the Chehalis River and then west to the Pacific Ocean to create extensive outwash plains ${ }^{6,7,10}$. At its maximum extent, the glacier stretched from the Cascade Range to the Olympic Mountains and extended south as far as Tenino, Wash., in Thurston County, occupying all of the lowland area and lower mountain valleys. The glacier reached altitudes up to 4,000 feet along the mountain front ${ }^{10}$; 6,000 feet near the present day United States-Canada border; 3,000 feet near Seattle; 2,200 feet near Tacoma; and less than 1.000 feet near Olympia. 1,4, 10

$\mathrm{D}$ ue to a global warming trend, the Vashon Glacier began retreating from its terminus about 17.000 years ago. As it retreated, meltwater from the glacier again formed large proglacial lakes. One of the early proglacial lakes that formed in the Pierce County area was Lake Puyallup $^{9,13}$ (fig. 1). Discharge from the proglacial lake cut outwash channels into the upland west of the proglacial lake, and its water and coarse sediment were spread over the central and western parts of this upland region. ${ }^{2,13}$ Large volumes of water from the lake flowed south, originally through the Ohop Valley Spillway. As the ice retreated northward lake levels dropped, and successively lower channel spillways were used: Muck Creek and Kirby, Clover Creek, and South Tacoma Channels, respectively 9,13 (fig. 1).

$$
\prod \begin{aligned}
& \text { he large } \\
& \text { volumes of }
\end{aligned}
$$

water flowing through these spillways modified the upland landforms and, in some places, eroded away sediments deposited during the glacial advance. Coarse sediment, known as the Steilacoom Gravel, was also deposited on the upland by water flowing through the intersecting channels and braided streams that further conveyed the water away from the proglacial lake.2,13 This gravel deposit is consistently coarse over the central Pierce County upland area. Stones in the Steilacoom Gravel are predominantly 1 inch in size and most do not exceed 3 inches. ${ }^{13}$ The thickness of the gravel is generally 20 feet or less with a maximum that rarely exceeds 60 feet. The resulting landscape is characterized by many shallow, elongated depressions and ice-contact depressions (kettles). The larger and deeper depressions are occupied by ground-water-fed lakes, such as American and Gravelly Lakes. ${ }^{13}$

$\mathrm{O}$ ver time, surface-water streams developed over this upland in many of the braided stream channels at the base of the outwash channels (Ohop Valley Spillway and Ohop Creek;

Muck Creek Channel and Muck Creek; Clover Creek Channel and Clover Creek; 


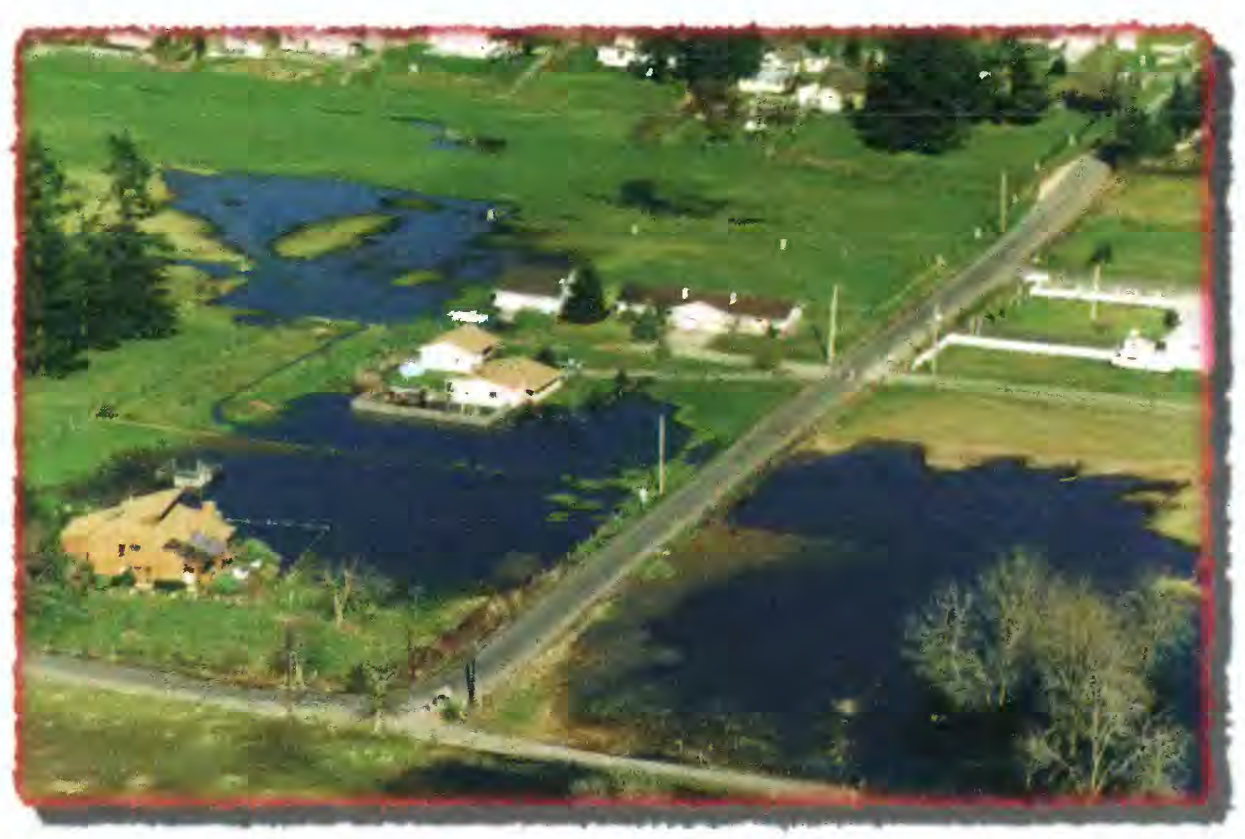

B. Ground-water flooding near Stony Lake, April 4, 1997 (photo by A.K. Williamson,

and the South Tacoma Channel and Flett Creek), except for the area west of the Kirby Channel. This outwash channel never developed surface-water streams instead, it contains many small, shallow, ground-water-fed lakes and marshes in the abandoned braided stream channels. Under certain conditions, however, when the ground-water levels rise to elevation that intersect and inundate low-lying areas west of the Kirby Channel, groundwater flooding occurs (fig. 2). This phenomenon is hard to distinguish from and is often mistaken for depression ground-water flooding, in which surface runoff collects in low-lying, low-

flooding, it can take several months for the ground water to recede from the area. Many areas of nearby Thurston County exhibited depression flooding during the winter of 1996-97. In most cases, the water levels of these ponded areas were above the surrounding water table.

ost of the flooding that occurred I in Pierce County during the winter and spring of 1996-97 is thought to be from ground-water flooding. Anecdotal accounts of the general location and extent of the flooding are shown on the map. A complete account of the flooding is unknown. The information available is based on oral communication and local

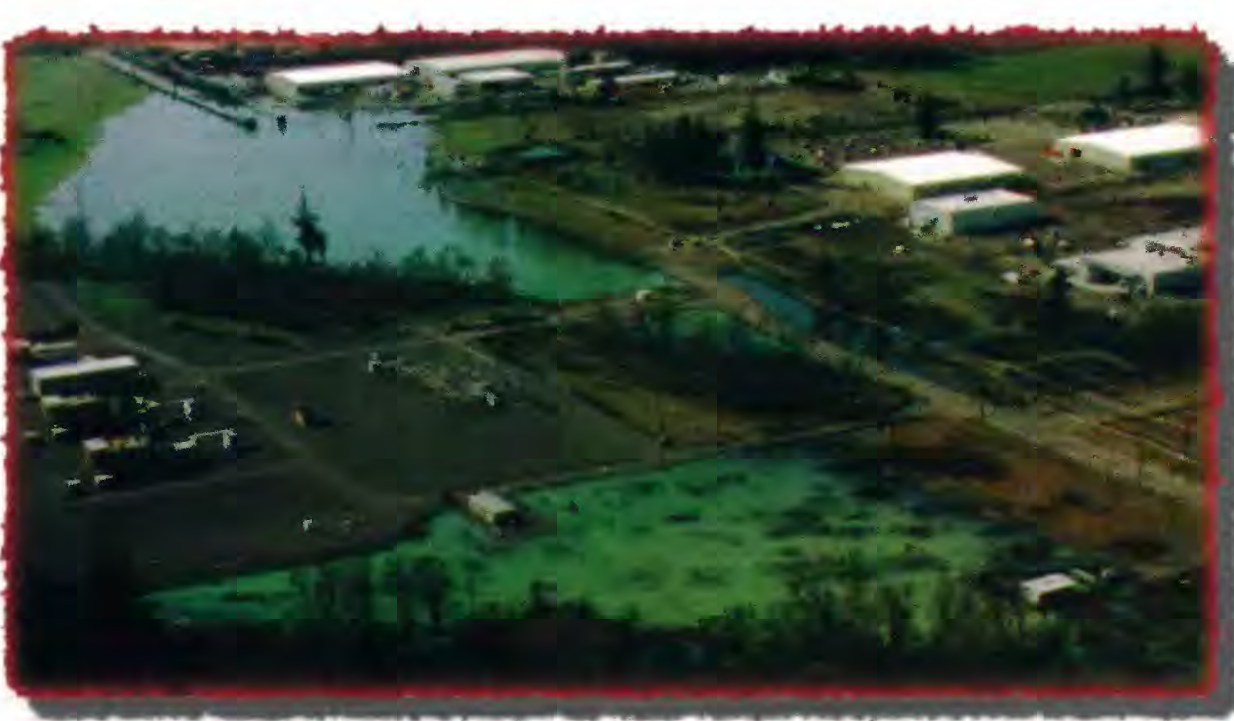
C. Ground-water flooding over 192nd Street East, April 4, 1997 (photo by A.K.
Williamson, USG 1997). reports in residential and industrial areas. Little if any information is known about he occurrence of Hooding in the unpopulated areas.

$\mathrm{G}_{\text {round-water elevations for the }}^{\text {ron }}$ ickson for March 1997' indicate that the ground-water flow follows the abandoned stream channel and flows southeast to northwest toward Spanaway Lake an local surface-water drainages at an estimated velocity of 1,000 feet per year. 5 This results in a unique phenomenon in some channels often called transient ground-water flooding, in which the ground-water flooding moves progressively down the outwash channel.

$T_{\text {ise observed ground-water flooding }}$

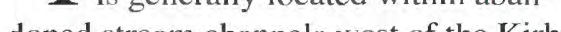
doned streannel. Several small gou hirby

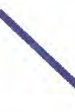

lakes are present in the northernmost 1997, this lake and the other lakes expanded and flooded homes (insert B) and roadways (insert C). The small lake near 192nd Street East expanded during Mar to an area covering about 25 acres, flooding 192nd Street East (insert C), closing the road and remained flooded for several months. Water over the roadwar was reported to be about 4 feet deep. Also, normally dry topographic low. within all hree abandoned stream A and D). 1 flooding in the westernmost abandoned stream channel is minimal because the area is unpopulated and lies within the Fort Lewis Military Boundary. What is known is that the 36 -inch culverts near channel; the only named one is Stony Lake. During the flooding event of March

Information on the depth and extent of

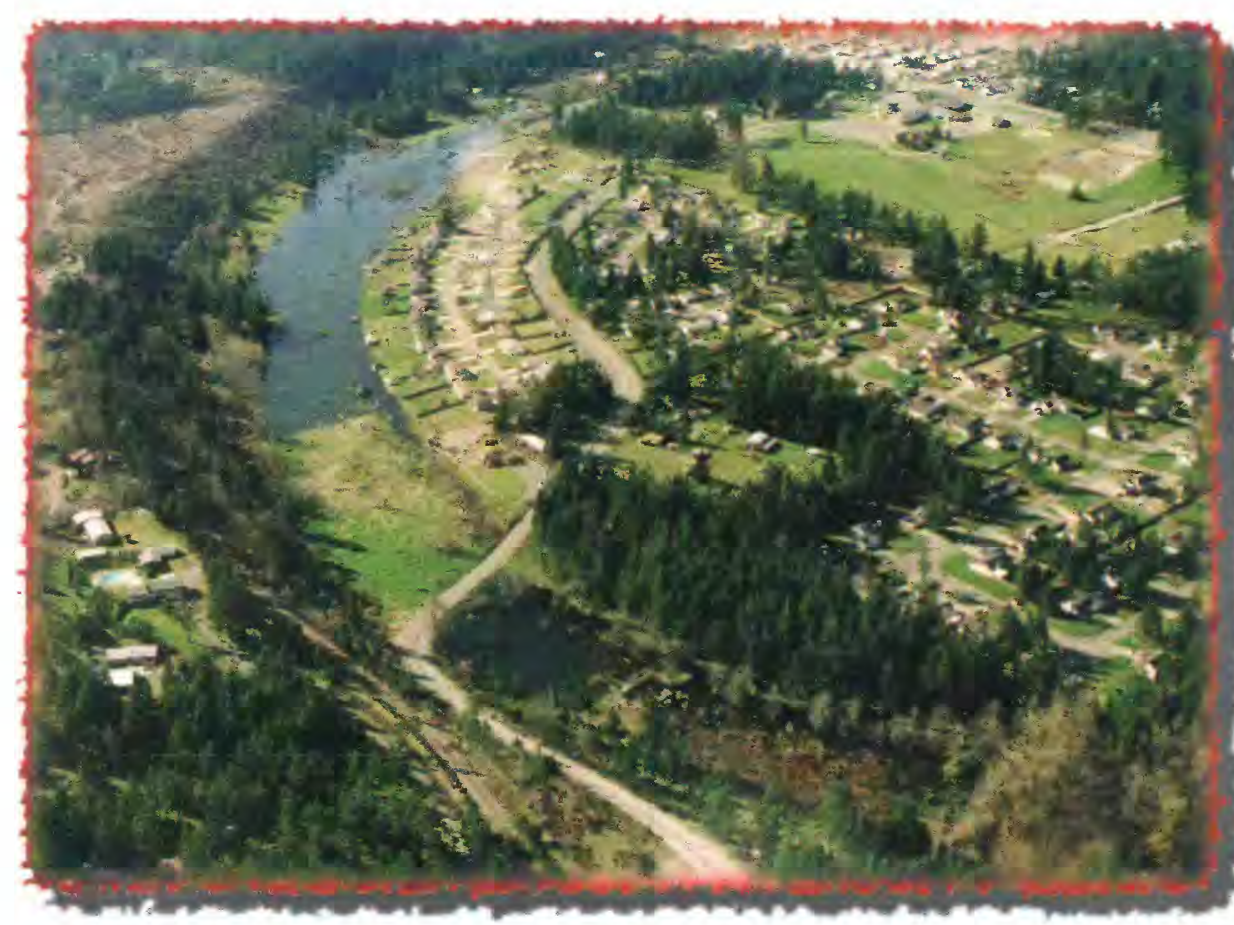
D. Ground-water flooding near Eustis Road, April 4, 1997 (photo by A.K.
Williamson, USGS 1997).

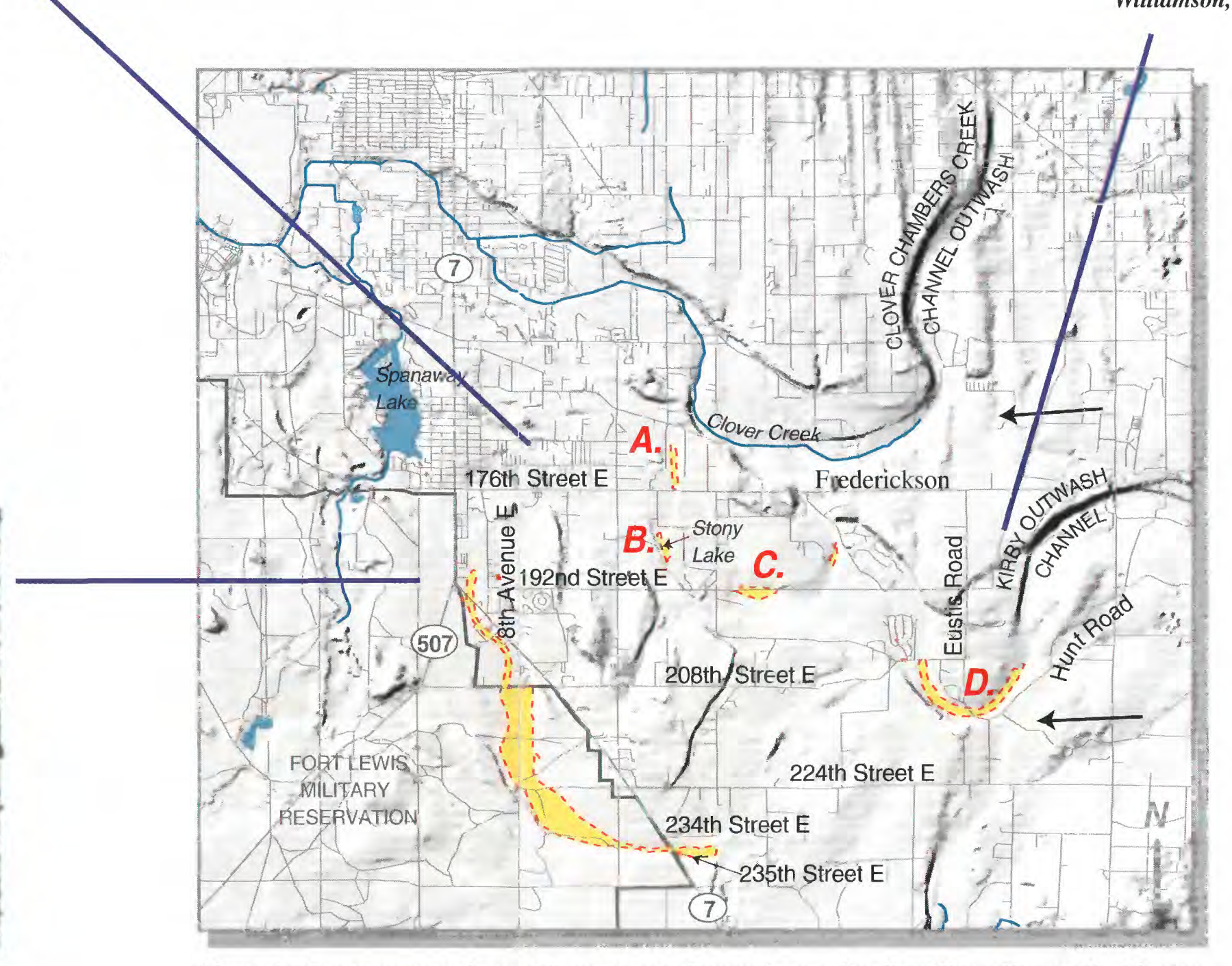

Figure 2. Known areas and approximate extent of ground-water flooding, Pierce County, Washington, 235th Street East and Highway 7 and near 208th Street East and 8th Avenue East were filled with moving water during the flooding in February and March 1999. ${ }^{\circ}$ Water also backed up against 208th Street East and floded Highway 7 with 1.5 feet to 507 junction, closing the rod for a short times

The conditions that have been associated with the incidence of ground-water flooding are sequential ( 2 or 3 ) years of above-average precipitation, summers. The excess precipitation increases the recharge to the ground-water system, resulting in higher ground-water levels. Cooler temperatures reduce the amount of evapotranspiration from plants and water bodies, which helps to maintain the higher ground-water levels. These factors, combined with the hydrogeologic properties of the glacial deposits, lead to increased ground-water storage is exceeded, ground-water flooding o c curs.

Other conditions that may also contribu 2 oped forested areas into developed commercial and residential areas potentially reduces the evapotranspiration and may increase the rate and amount of precipitation available to recharge the ground-water system through septic systems, irrigation, and certain types of drainage systems. changes in land use. The conversion of undevel- 
'Blunt, D.J., Easterbrook, D.J., and Rutter, N.W., 1987, Chronology of Pleistocene sediments in the Puget Lowland, Washington, in Schuster, J.E., ed., Selected papers on the geology of Washington: Olympia, Wash., Washington Division of Geology and Earth Resources Bulletin 77, p. 321-353.

${ }^{2}$ Bretz, JH., 1913, Glaciation of the Puget Sound region: Washington Geological Survey Bulletin no. 8, 244 p.

${ }^{3}$ Bucich, P., Pierce County Public Works, written commun., 1999.

${ }^{4}$ Easterbrook, D.J., 1979, The last glaciation of northwest Washington, in Armentrout, J.M., Cole, R.M., and Ter Best, Harry, Jr., eds., 1979. Cenozoic paleogeography of the western United States: Society of Economic Paleontologists and Mineralogists Pacific Section, Pacific Coast Paleogeography Symposium 3, p. 177-189.
${ }^{5}$ Hart Crowser, 1997, Flooding assessment, 192nd Street East and Canyon Road, Frederickson, Washington: Seattle, Wash., Hart Crowser. Report J-4736, 16 p.

${ }^{6}$ Noble, J.B., and Wallace, E.F., 1966 , Geology and ground-water resources of Thurston County, Washington: Olympia, Wash., Washington Division of Water Resources Water Supply Bulletin 10, v. $2,141 \mathrm{p}$.

${ }^{7}$ Porter, S.C., and Swanson, T.W., 1998, Radiocarbon age constraints on rates of advance and retreat of the Puget Lobe of the Cordilleran Ice Sheet during the last Glaciation: Quaternary Research, v. 50, no. 3 , p. 205-213.

${ }^{8}$ Schmidt, H., Pierce County Water Programs, oral commun., July 24, 1999.

9Thorson, R.M., 1979, Isostatic effects of the last glaciation in the Puget Lowland, Washington: Seattle, Wash., University of Washington, Ph.D. dissertation, 154 p., 1 pl.
I 1980 , Ice-sheet glaciation of the Puget Lowland, Washington, during the Vashon Stade (late Pleistocene): Quaternary Research. v. 13, p. 303-321.

${ }^{11}$ U.S. Army Corps of Engineers, 1997, Post event report--Winter storm of 199697, Federal Disaster DR 1 159, Western Washington Summary: Seattle. Wash., Federal Emergency Management Agency, final document May 16, 1997, 38 p.

${ }^{12}$ Visokey, Adrian P., 1995, Determination of 100-year ground-water flood danger zones for the Havana and Bath areas, Mason County, Illinois: Illinois State Water Survey, Contract Report 584, 15 p.

${ }^{13}$ Walters, K.L. and Kimmel, G.E., 1968. Ground-water occurrence and stratigraphy of unconsolidated deposits, central Pierce County, Washington: Olympia, Wash., Washington State Department of Water Resources Water Supply Bulletin no. 22,428 p.

Watural hazards include flooding, landslides, volcanic eruptions, and earthquakes. The best protection 1 for you, your family, and community is to find out if you live in a natural hazard zone. Ask your public officials advice on where to go and what to do during an emergency. Then develop an emergency plan with your family, community, or business to help you safely respond during any natural disaster. Advice and information on the potential natural hazards in your area may be obtained by contacting your local engineering or emergency management officials.

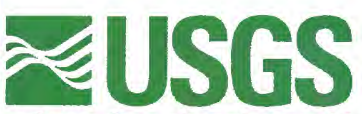

science for a changing world

\section{Myrtle Jones}

(253) 428-3600 ext 2617

e-mail: majones@usgs.gov

\section{Joseph Jones}

(253) 428-3600 ext 2684

e-mail: jljones@usgs.gov

\section{Theresa Olsen}

(253) 428-3600 ext 2652

e-mail: tdolsen@usgs.gov

U.S. Department of the Interior U.S. Geological Survey

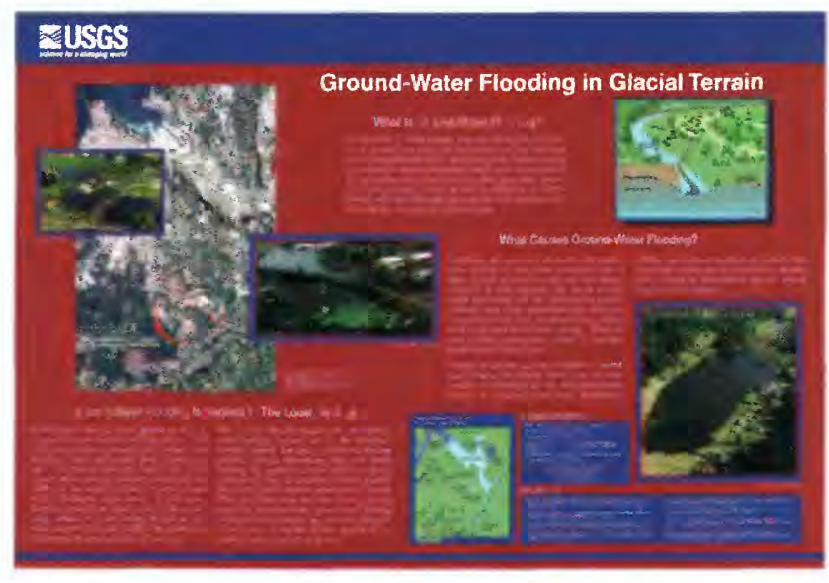

Acknowledgments:

Illustration and Design: Connie Dean

Document Layout: Ginger Renslow Technical Editor: John Clemens
For more information or to order a copy of the poster (WRIR-00-4181) based on this fact sheet, contact:

District Chief

U.S. Geological Survey, WRD 1201 Pacific Avenue, Suite 600 Tacoma, WA 98402 (253) $428-3600$

e-mail: lafuste@usgs.gov www.wa.water.usgs.gov 